\title{
MICROCLIMATE MODELS TO PREDICT THE CONTRIBUTION OF FACADE MATERIALS TO THE CANOPY LAYER HEAT ISLAND IN HOT-HUMID AREAS
}

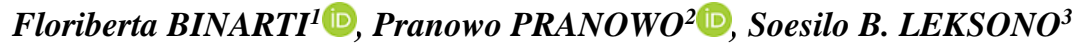

DOI: 10.21163/GT_2020.151.21

\begin{abstract}
:
This paper aims to study a microclimate model for predicting the role of façade materials to the Canopy Layer Heat Island. ENVI-met was selected to model the microclimate of four street canyons in Yogyakarta, which vary in façade materials, street orientation, and land cover. Three to four-day field measurements in each canyon were intended to obtain microclimate data at pedestrian level, wind speed and orientation at the boundary layer for simulation input and validation. The validation study confirms the accuracy of ENVI-met simulations in predicting air temperature and relative humidity when the initial wind speed at the boundary layer is $>1.5 \mathrm{~m} / \mathrm{s}$. These input data affected on the simulation results. However, the "comparison" feature offers a facility to analyze the modification in the air temperature and mean radiant temperature in the street canyon due to higher thermal transmittance and higher surface albedo façade materials. The results show that street orientation, big trees along the street and sky view factor significantly affect the pattern of air temperature modified by the increasing thermal transmittance and albedo of the façades.
\end{abstract}

Key-words: Albedo, Canopy Layer Heat Island, Façade materials, Microclimate model, Thermal transmittance.

\section{INTRODUCTION}

Many studied the role of surface materials in the microclimate of the surrounding and the Canopy Layer Heat Island (CLHI). Erell et al. (2014), Ghaffarianhoseini et al. (2015), Kyriakodis \& Santamouris (2017), Lee \& Meyer (2018), Santamouris et al. (2012), Taleghani (2018) proved the ability of high albedo $(\alpha)$ materials to remediate the extremely heat by reflecting a large portion of solar radiation to the sky that further reduces the sensible heat flux. The contribution of the combination of high $\alpha$ and high solar emissivity materials, so-called cool materials, to the reduction of the ambient temperature (Ta) has been observed by Santamouris et al. (2012) and Kyriakodis \& Santamouris (2017).

Some of them (Chokhachian et al., 2017; Erell et al., 2014; Taleghani, 2018) argued the negative impacts of the radiative property on the surrounding thermal environment. Taleghani (2018) showed that altering the $\alpha$ of the roof may not influence the near ground surface thermal conditions. Using high $\alpha$ materials lowers the Ta, but elevates the heat stress at the pedestrian level (Erell et al., 2014).

\footnotetext{
${ }^{1}$ Universitas Atma Jaya Yogyakarta, Department of Architecture, 55481 Babarsari 44, Indonesia, flo.binarti@gmail.com,floriberta.binarti@uajy.ac.id,;

${ }^{2}$ Universitas Atma Jaya Yogyakarta, Department of Informatics, graduate program, 55481Babarsari 44, Indonesia pranowo@uajy.ac.id,;

${ }^{3}$ Universitas Atma Jaya Yogyakarta, Department of Architecture, 55481 Babarsari 44, Indonesia, sb_leksono@yahoo.com.
} 
Meanwhile, Chokhachian et al. (2017) found that a light color wall with less solar absorption is worse for outdoor comfort during hot periods in Munich compared to dark ones. However, only few studies observed the effect of the thermal properties of the material on the CLHI. Thermal inertia of material causes delaying of material's thermal response. Materials with high thermal inertia can mitigate CLHI by moderating the rate of stored heat at night and the emitted heat to the atmosphere (Sen et al., 2015). It must be noted that the magnitude of reflected solar radiation and the effect on outdoor thermal comfort is highly context-dependent (Laureti et al., 2018; Lee \& Mayer, 2018; Taleghani, 2018).

We found limited studies on the impacts of facade materials on the CLHI. Chokhachian et al. (2017) conducted a parametric study of facade materials with different $\alpha$ in Munich, which resulted in a proportionally reverse relationship among solar absorption, surface temperature (Ts), and mean radiant temperature (Tr). A higher solar absorption facade reflects less solar radiation, which further cools the surrounding space. Different facade materials affect smaller on local $\mathrm{Tr}$ values than the difference in solar absorption percentages. Gael (2014) carried out a study on the effect of facade properties ( $\alpha$ and thermal transmittance or U-value) on the canopy layer microclimate within city blocks in Budapest. According to Gael (2014), change in U-values insignificantly modified the diurnal cycles. The effect of $\alpha$ on the Ta within UCL becomes very noticeable during the day.

The relationship between $\operatorname{Tr}$ and $\alpha$ is directly proportional with mostly limited effects on the daytime. Higher $\alpha$ reduces the Ts, but increases the Tr. The $\operatorname{Tr}$ within the canopy is a function of built form and facade density indicated by the uneven effect of $\alpha$ in time and per configuration. The canopy layer $\operatorname{Tr}$ is mainly driven by the change in $\alpha$, but hardly affected by facade's U-value (Gael, 2014).

Except Fox et al. (2018), who used a terrestrial multispectral sensor calibrated with an empirical line method to measure and predict the distributions of spectral reflectance from urban vertical surfaces, most other studies employ ENVI-met program. Gael (2014) utilized ENVI-met to simulate the canopy layer microclimate and MATLAB to analyze the results. Aside from using ENVI-met to estimate the microclimate elements of the urban block, Chokhachian et al. (2017) employed TRNSYS to simulate the effect of different surface materials on the $\operatorname{Tr}$ and Ta inside a canyon. The Tr values resulted from TRNSYS replaced the values calculated by ENVI-met due to inaccuracy issues. The ENVI-met calculations of Tr tend to highly estimate compared to on-site measurements in studies conducted in Dhaka, Bangladesh (Sharmin et al., 2017) and Freiburg, Germany (Chen et al., 2014). A study using ENVI-met models to predict the Tr of an archaeological park in a tropical area confirms the inaccuracy ranging from $24.8 \%$ to $30.1 \%$. However, setting up the solar radiation in "Solar Adjustment Factor" (SAF) feature and the cloud cover in "Cloud Condition" feature could improve $19.7 \%$ of the accuracy (Binarti et al., 2020a).

This study aims to predict the response of surface materials of building facade along the streets and the effects on the CLHI. Since the current developed simulation program is possible to predict large simulation area with acceptable accuracy, we employed ENVI-met and explored the advantages and limitations to model the microclimate of the street canyons at pedestrian level (CLHI), which varied in the facade materials of buildings along the streets. 


\section{CHARACTERISTICS OF THE STUDY AREA}

Four street canyons in Yogyakarta - i.e., Urip Sumoharjo Street (US), C. Simanjuntak Street (CS), Palagan Tentara Pelajar Street (PT), and Agus Salim Street (AS), - were selected based on the street orientation, façade materials, green area, building density and height. Ivan \& Benedek (2017), Paramita \& Suparta (2019) and Ursu (2019) mentioned that built-up area, green area, building density and height affect the land surface temperature and microclimate. The street canyons are situated at the latitude of $7^{\circ} 48^{\prime} 5^{\prime}$ 'S and the longitude of $110^{\circ} 21^{\prime} 52^{\prime \prime} \mathrm{E}$ that belongs to hot-humid climates (Koppen Aw).

According to Wicahyani et al. (2014), the UHI phenomenon also appeared in Yogyakarta. The strengthening phenomenon is described by the significant differences of the surface temperature between urban and rural area, which reveal on Landsat 8 OLI/TIRS satellite images retrieved on May 5, 2018, at 06:32:03 (9 K) and August 25, 2018, at 21:50:13 (13 K) (Binarti et al., 2020b).

As a medium-scale city, the height to width ratio (h/w) or the sky view factor (SVF) of the street canyons in Yogyakarta varies slightly. Despite the variety in building density and height, the average SVFs measured using a fish-eye camera and calculated by SVF calculator (Lindberg \& Grimmond, 2010) look similar. They range from 0.82 to 0.89 (see Table 1). As busy commercial streets, window glazing and aluminum/metal cladding dominate the facades along US street and CS street. Whereas, timber and brick prevail on the façade along AS street. Large trees along the PT street appear more dominant compared to those along the other canyons.

Table 1.

Four street canyons and their characteristics.

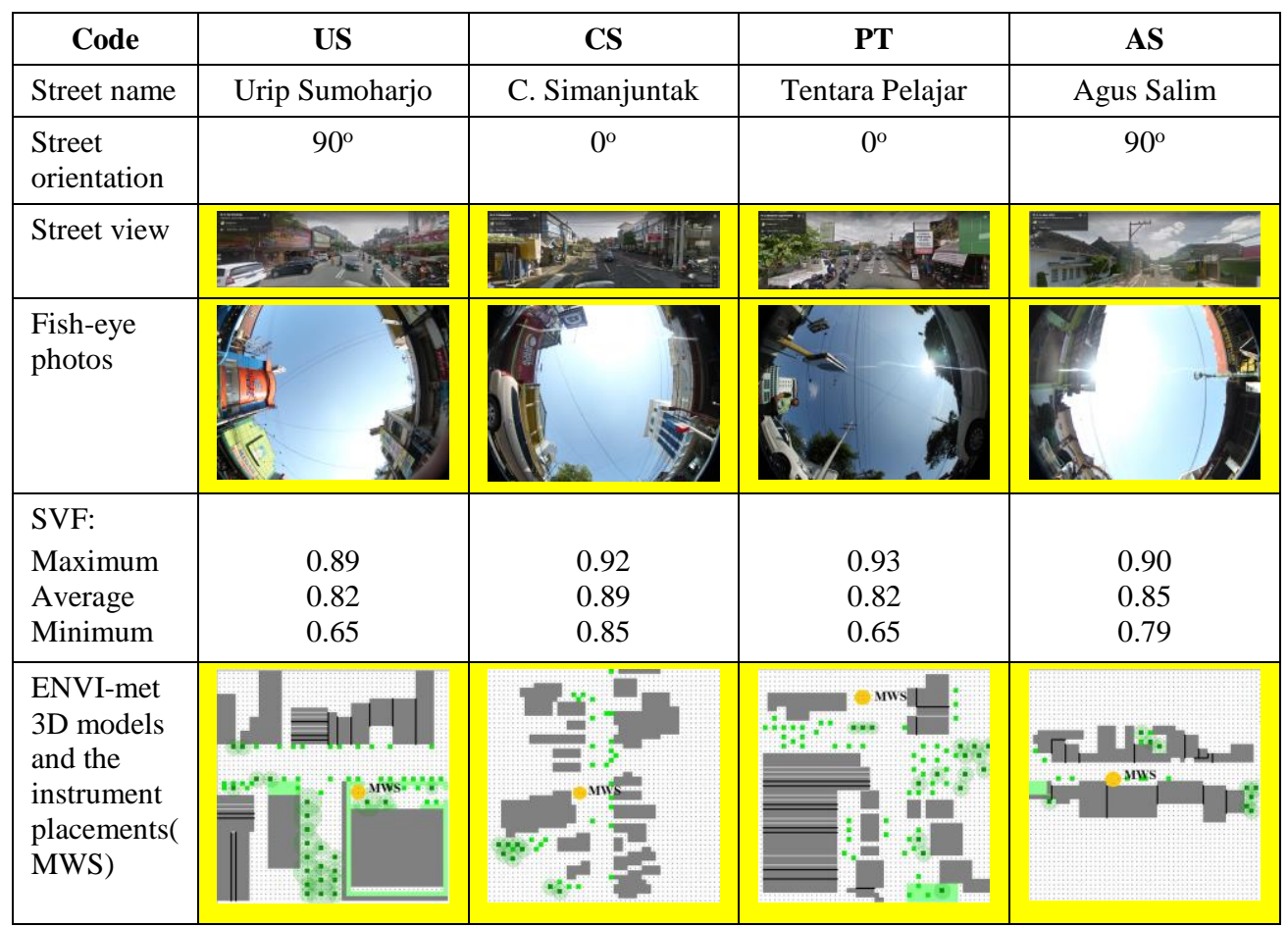




\section{METHODOLOGY}

\subsection{Field measurements for input data and validation}

ENVI-met is the most widely used outdoor microclimate software due to the capability in predicting the outdoor microclimate at a very high spatial resolution (Taleghani, 2018) and the availability of free version with acceptable accuracy (Salata et al., 2016; Binarti et al., 2020a). However, several studies mentioned the inaccuracy of this software especially in predicting the $\operatorname{Tr}$ (Binarti et al., 2020a; Chen et al., 2014; Sharmin et al., 2017) and the wind speed (v) (Acero \& Herranz-Pascual, 2015). To increase the accuracy, ENVI-met provides forcing method by inputting 24-hour for the simple forcing or annual microclimate data for the full one at a certain point within the study area.

To measure the microclimate of the street canyon - i.e., Ta, relative humidity $(\mathrm{RH}), \mathrm{v}-$ a micro weather station (MWS) PCE FWS-20 equipped with ESPEC RS-13 with two channels was installed at the pedestrian level $( \pm 1.2 \mathrm{~m})$. One channel of ESPEC RS-13 connects the data logger to a globe thermometer to measure the globe temperature (Tg), and the other connects the data logger to a soil thermometer to measure the soil temperature (Ts). We used microclimate data retrieved from these instruments for input data and validation study. For the validation study, we compared field-measured data of Ta, RH, v, and $\mathrm{Tr}$ to simulated Ta, RH, v, and Tr. The Tr was calculated using the classical equation of Tr in ASHRAE Handbook (ASHRAE, 1997). The same micro weather station at the height of $10 \mathrm{~m}$ measured the $\mathrm{v}$ at the boundary layer for input data at initial time of ENVI-met simulations. All instruments comply with ISO 7726 (Johannson et al., 2014).

\subsection{Modeling the microclimate using ENVI-met}

This study employed the free version ENVI-met v.4.4.3 (ENVI-met, 2019) with $50 \mathrm{x}$ $50 \times 30$ cells as the maximum grid number in x-, y-, and z-axis. Binarti et al. (2020a) mentioned several methods to maximize the capability of free version ENVI-met in predicting the $\operatorname{Tr}$ of an archaeological tourist area in hot-humid climate (at the latitude $7^{\circ} 45^{\prime} \mathrm{S}$ and the longitude of $\left.110^{\circ} 30^{\prime} \mathrm{E}\right)$. Maximizing the spatial resolution is the first method adopted in this study.

Table 2.

Meteorological data for simulation input.

\begin{tabular}{|c|c|c|c|c|}
\hline Street canyon & US & CS & PT & $\mathbf{A S}$ \\
\hline Date & $07 / 09 / 2019$ & $30 / 09 / 2019$ & $26 / 09 / 2019$ & $10 / 09 / 2019$ \\
\hline Ta max at $1.2 \mathrm{~m}\left({ }^{\circ} \mathrm{C}\right)$ & 32.54 at $12: 00$ & $34: 67$ at $14: 00$ & 35.24 at 13:00 & 36.03 at $13: 00$ \\
\hline Ta min at $1.2 \mathrm{~m}\left({ }^{\circ} \mathrm{C}\right)$ & 22.02 at $04: 00$ & 23.23 at $06: 00$ & $23: 03$ at $05: 00$ & 21.82 at $05: 00$ \\
\hline RH max at $1.2 \mathrm{~m} \mathrm{( \% )}$ & 84.83 at $04: 00$ & 89.25 at $06: 00$ & 91.42 at $05: 00$ & 97.17 at $06: 00$ \\
\hline RH min at $1.2 \mathrm{~m} \mathrm{( \% )}$ & 39.08 at $11: 00$ & 33.00 at $15: 00$ & 33.75 at $12: 00$ & 29.17 at $13: 00$ \\
\hline Initial time & $14: 00$ & $14: 00$ & $12: 00$ & 08:00 \\
\hline $\begin{array}{l}\mathrm{v}(\mathrm{m} / \mathrm{s}) \text { and wind } \\
\text { direction at } 10 \mathrm{~m} \text { high }\end{array}$ & $2.97 \& 270$ & $1.89 \& 180$ & $1.56 \& 135$ & $1.08 \& 270$ \\
\hline \multicolumn{5}{|c|}{ Ts $\left({ }^{\circ} \mathrm{C}\right)$ and RHs $(\%)$ at the depth of } \\
\hline (1) $0-20 \mathrm{~cm}$ & $29.6-66.0$ & $34.3-79.0$ & $28.4-62.0$ & $26.1-55.7$ \\
\hline (2) $20-50 \mathrm{~cm}$ & $28.6-74.0$ & $33.3-87.0$ & $27.4-70.0$ & $25.1-63.7$ \\
\hline (3) $>50 \mathrm{~cm}$ & $27.0-78.0$ & $31.5-91.0$ & $25.9-74.0$ & $24.3-67.7$ \\
\hline
\end{tabular}

By using $3 \mathrm{~m}$ resolution for $\mathrm{dx}$ and $\mathrm{dy}$, the maximum grid number simulation area enables to cover $150 \times 150 \mathrm{~m}^{2}$. We did not apply the telescoping factor since the maximum building height only raises $23 \mathrm{~m}$. In the study conducted by Binarti et al. (2020a), the "Solar 
Adjustment Factor" (SAF) feature contributes to a 19.7\% improvement of the accuracy in calculating the Tr. Based on the comparison between field measure and simulated solar radiation flux, Binarti et al. (2020a) used $67.6 \%$ for the SAF of simulations on September 21,2018 , and $74.4 \%$ for the SAF of simulations on October 17, 2018. Since the location of the study areas has proximity to the archaeological tourist area, this study applied $70 \%$ for the SAF. Cloud conditions were set up at 0 octas (clear sky).

Table 2 presents the meteorological data used for simulations of each area retrieved from three- to four-day field measurements. To obtain high accuracy of the simulation results, this study selected the initial time at the time when high v occurred.

\section{RESULTS AND DISCUSSIONS}

\subsection{Results of the validation study}

To validate ENVI-met simulation results, we compared simulation results of the Ta, $\mathrm{RH}, \mathrm{v}$, and $\mathrm{Tr}$ at the instrument installation points to measurement results of the same microclimate elements. Fig. 1 presents the results of microclimate simulations of four street canyons with existing façade materials. By excluding the simulation results of AS street canyon, the accurate predictions of Ta with the discrepancy ranging from 0 (US street at 00:00 and 04:00 and CS street at 0:00) to -0.07 (CS street at 16:00) can be achieved. Predictions of the $\mathrm{RH}$ and $\mathrm{Tr}$ are less accurate compared to the one of the Ta. The discrepancies of RH range from 0 (US at 00:00 and 04:00) to 0.18 (CS at 16:00 and PT at noon); whereas, the discrepancies of $\mathrm{Tr}$ range from -0.02 (CS at 08:00) to -1.16 (AS at 04:00). Although all initial wind directions at the boundary layer are (mostly) parallel to the street orientation, Fig. 1 shows significant discrepancies in the v prediction, which range from 0.01 (PT at noon) to 1 (PT at 0:00).

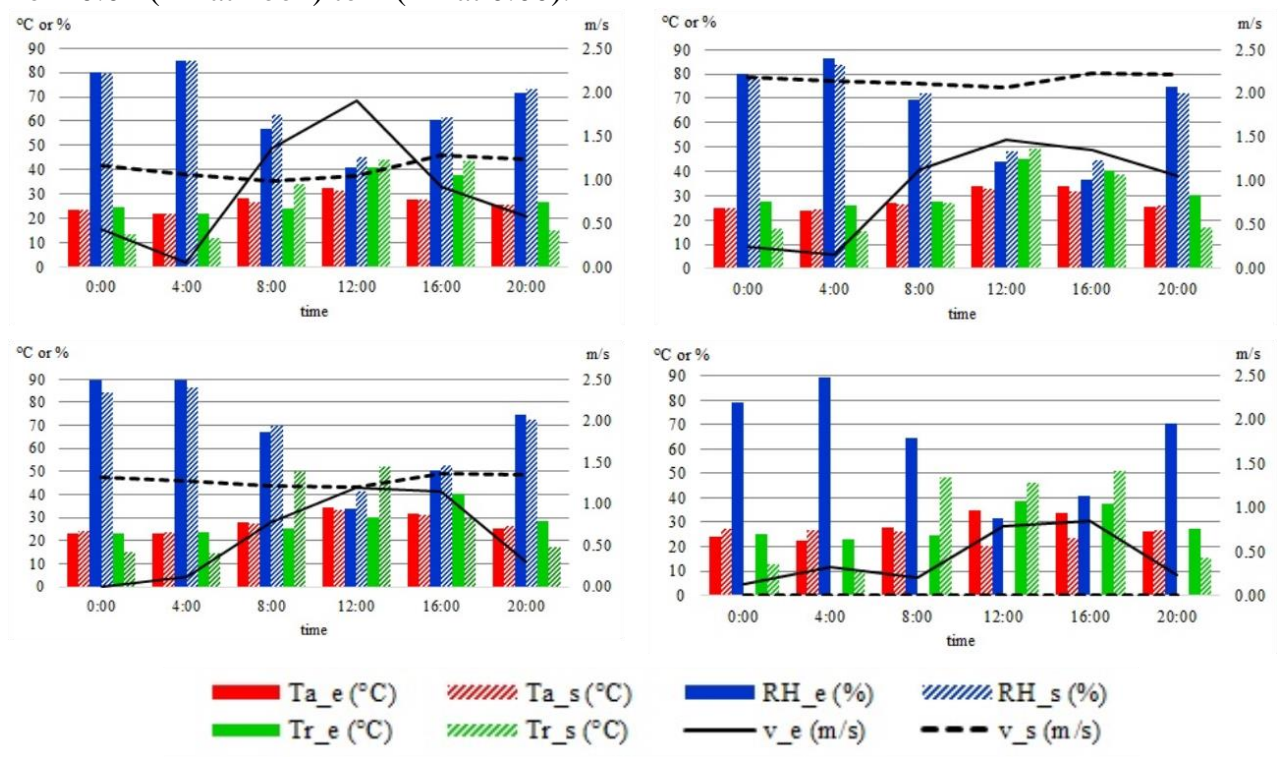

Fig. 1. Comparison between simulated and measured microclimate data of US area (left-above), CS area (right-above), TP area (left-bottom), and AS area (right-bottom) (Notes: _e: existing; _s: simulated). 
The wind (speed) in CS and PT street canyon, which have north-south orientation, behaves similarly. ENVI-met tends to overestimate the $\mathrm{v}$ in the nighttime. At noon ENVImet could predict the $\mathrm{v}$ accurately or with a slight discrepancy. Lower initial $\mathrm{v}$ at $10 \mathrm{~m}$ high resulted in lower accurate predictions shown in the predictions of the Ta (maximum discrepancy $=-0.70$ ), RH (maximum discrepancy $=-999$ ), $\mathrm{v}$ (no results) and $\operatorname{Tr}$ (maximum discrepancy $=-1.16$ ) of AS area. These results confirm the statements of Nyuk Hien et al. (2012) that low initial $\mathrm{v}$ at the boundary layer for the ENVI-met input data produces inaccurate simulation results.

\subsection{The role of wall material with higher $U$-value}

At the second stage, we replaced all wall materials with $45 \mathrm{~cm}$-thick, burned brick. This material has high U-value and thermal inertia. Maps of comparison between existing façade materials and $45 \mathrm{~cm}$-thick, burned brick walls of US and CS area show similar Ta differences (Fig. 2). In the whole day, Ta slightly increases due to high U-value walls. Only at 20:00 the change in wall materials in CS area slightly reduces the Ta. The increase in Ta in US area is much higher than that of in PT area. The maximum increase in the Ta occurred at noon - i.e., $027 \mathrm{~K}-0.44 \mathrm{~K}$ for US area and $0.1 \mathrm{~K}-0.2 \mathrm{~K}$ for PT area. In other areas (CS and AS), increase in the Ta due to higher U-value wall materials only occurred in the day. In the night, the reduction of the Ta in CS area is higher than that of in AS area. However, wall material with higher U-value generally tends to increase the Ta in the day (Fig. 2).
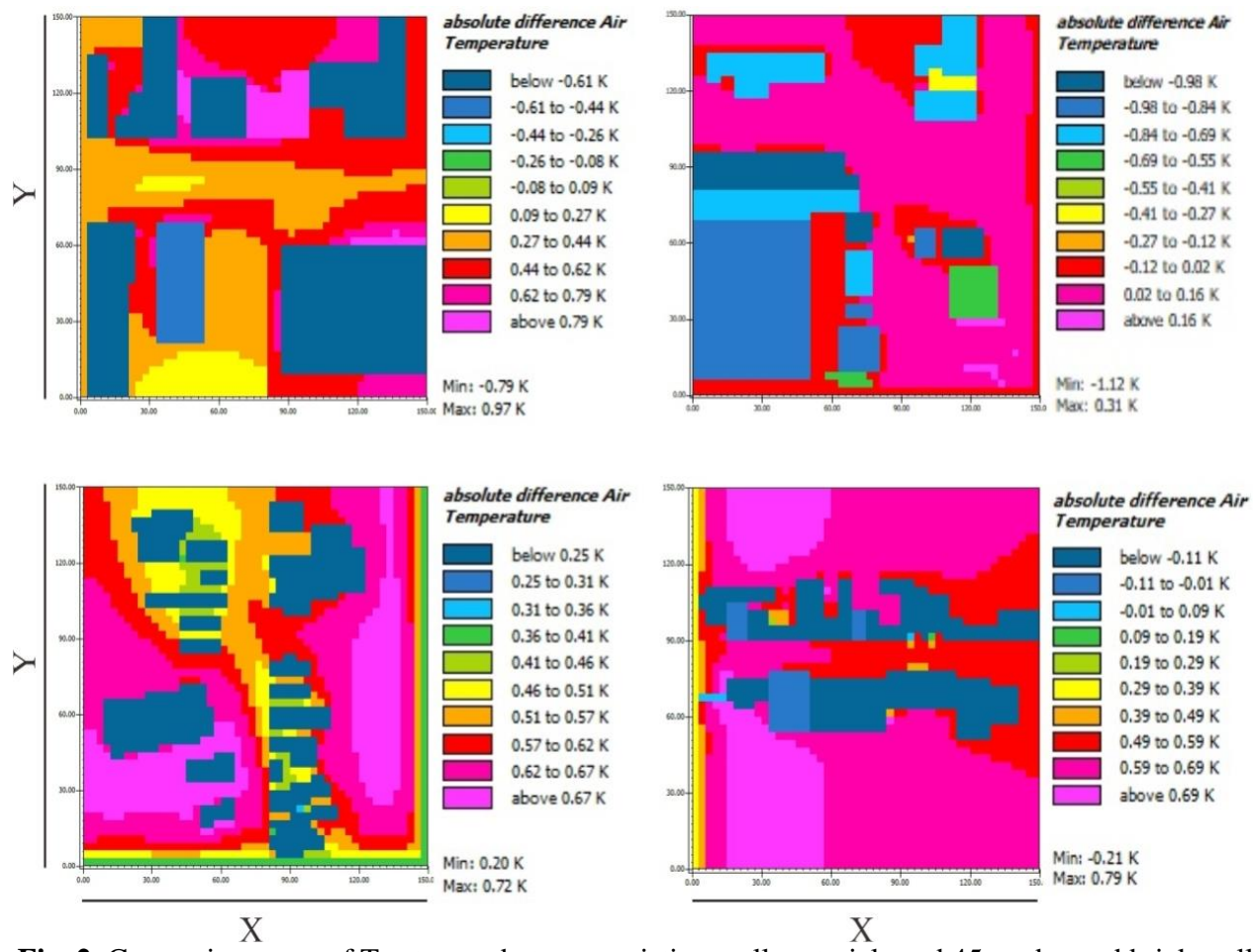

Fig. 2. Comparison map of Ta at noon between existing wall materials and $45 \mathrm{~cm}$ burned brick walls in US area (left-above), PT area (right-above), CS area (left-bottom) and AS area (right-bottom). 
Increasing the U-value of wall materials in both areas cannot modify the v. Simulations of the $\mathrm{Tr}$ in US street canyon increase the $\mathrm{Tr}$ due to the $45 \mathrm{~cm}$-thick, burned brick walls. The maximum increase $(6.54 \mathrm{~K})$ occurred at $04: 00$, and the minimum increase $(2.27 \mathrm{~K})$ occurred at 20:00. The simulation results of Tr in PT, CS, and AS street canyons show similar results with much lower $\operatorname{Tr}$ differences compared to the $\operatorname{Tr}$ differences in US area. From 20:00 to 08:00, the Tr in CS and AS street canyons decrease from $0.07 \mathrm{~K}$ to $0.16 \mathrm{~K}$.

\subsection{The role of wall material with higher $\alpha$}

At the third stage, we added a high surface albedo $(\alpha=0.9)$ coating on the external surface of $45 \mathrm{~cm}$-thick burned brick walls. Comparison maps of Ta between urban areas with existing wall materials and ones with $45 \mathrm{~cm}$-thick burned brick walls combined with high surface wall $\alpha$ show that contributions of high external surface wall $\alpha$ to the Ta of street canyons are diverse and do not have a specific pattern.

In US street canyon, adding high $\alpha$ coating on the external surface walls reduces the Ta in the early morning and the night (16:00 - 04:00). This pattern also appears in PT street canyon. At 08:00 high external wall $\alpha$ materials reduces the Ta in both street canyons. At noon due to the increasing $\alpha$, the Ta in US street canyon decreases. Whereas, the Ta in PT street canyon tends to increase. Although CS and AS street canyons have different orientation, the increase in external surface wall $\alpha$ created a very similar pattern of the Ta. The pattern of $\mathrm{Ta}$ as the effect of high external surface wall $\alpha$ materials is different from the pattern of $v$. Increase in wall $\alpha$ slightly raises the $\mathrm{v}$ in US street canyon, but it slightly reduces the $\mathrm{v}$ in AS street canyon. However, the increase in external surface wall $\alpha$ cannot modify the $\mathrm{v}$ in the north-south oriented street canyon (CS and PT).

Fig. 3 presents the comparison maps of $\operatorname{Tr}$ of street canyons between areas with existing wall materials and ones with high external surface wall $\alpha$. Effects of high $\alpha$ on $\mathrm{Tr}$ at 08:00-16:00 in four street canyons are similar. During that time, $\mathrm{Tr}$ increases due to high external surface wall $\alpha$, which the most significant effect appears in US street canyon. The whole day Tr in US and PT street canyons have the same pattern. These results confirm the results of previous studies on the role of $\alpha$ carried out by Chokhachian et al. (2017), Erell et al. (2014), and Taleghani (2018).
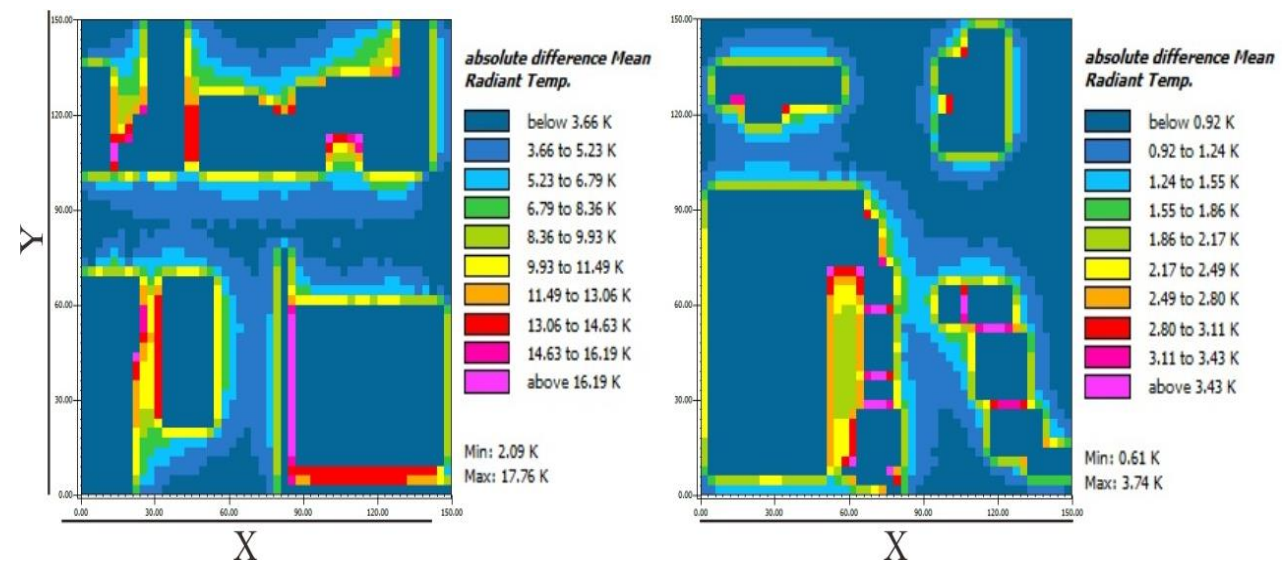

Fig. 3. Map of $\operatorname{Tr}$ at noon comparison between existing wall materials and high external surface albedo walls in US area (left), PT area (right). 


\subsection{High U-value vs. high $U$-value with high external surface $\alpha$}

Comparison maps between urban areas with high U-value and the ones with high Uvalue combined with high external surface $\alpha$ indicate the increase in Ta in the early morning and the night (at 00:00, 04:00, and 20:00) due to the additional high $\alpha$ coating (Fig. 4). Meanwhile, in the daytime (at 08:00-16:00), adding high $\alpha$ coating on the external surface walls tends to lower the Ta in the street canyons. However, adding high $\alpha$ coating on the external surface walls would raise the $\operatorname{Tr}$ the whole day as we observed in four street canyons.
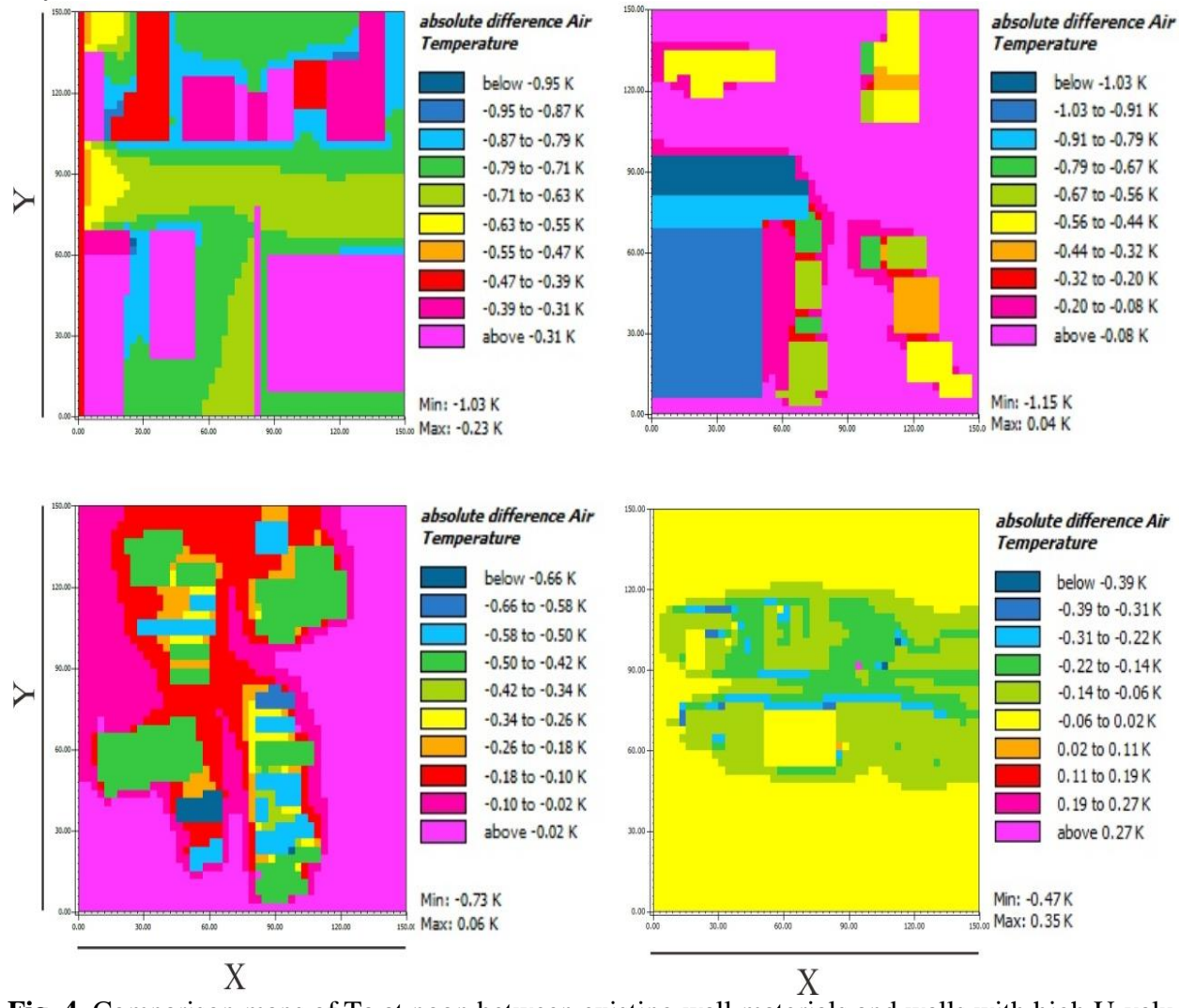

Fig. 4. Comparison maps of Ta at noon between existing wall materials and walls with high U-value and high external surface wall $\alpha$ in US area (left-above), PT area (right-above), CS area (left-bottom), and AS area (right-bottom).

Interesting results are shown by Fig. 5, which describes how street orientation determines the diurnal Ta profile. The Ta fluctuates especially in the daytime on the canyons with east-west orientation. Application of higher U-value and $\alpha$ on US canyons raises the Ta. Increasing the U-value and $\alpha$ of the façade in AS and CS canyons could reduce the $\mathrm{Ta}$ in the nighttime and the morning, but not at 12:00 and 16:00. The different effect on the Ta in US, CS, and AS canyons may be caused by the smaller SVF (the width and distance between buildings along the canyon) of the US canyon. In PT canyon, the presence of big trees along the street might moderate the effect of façade material change on the Ta. 

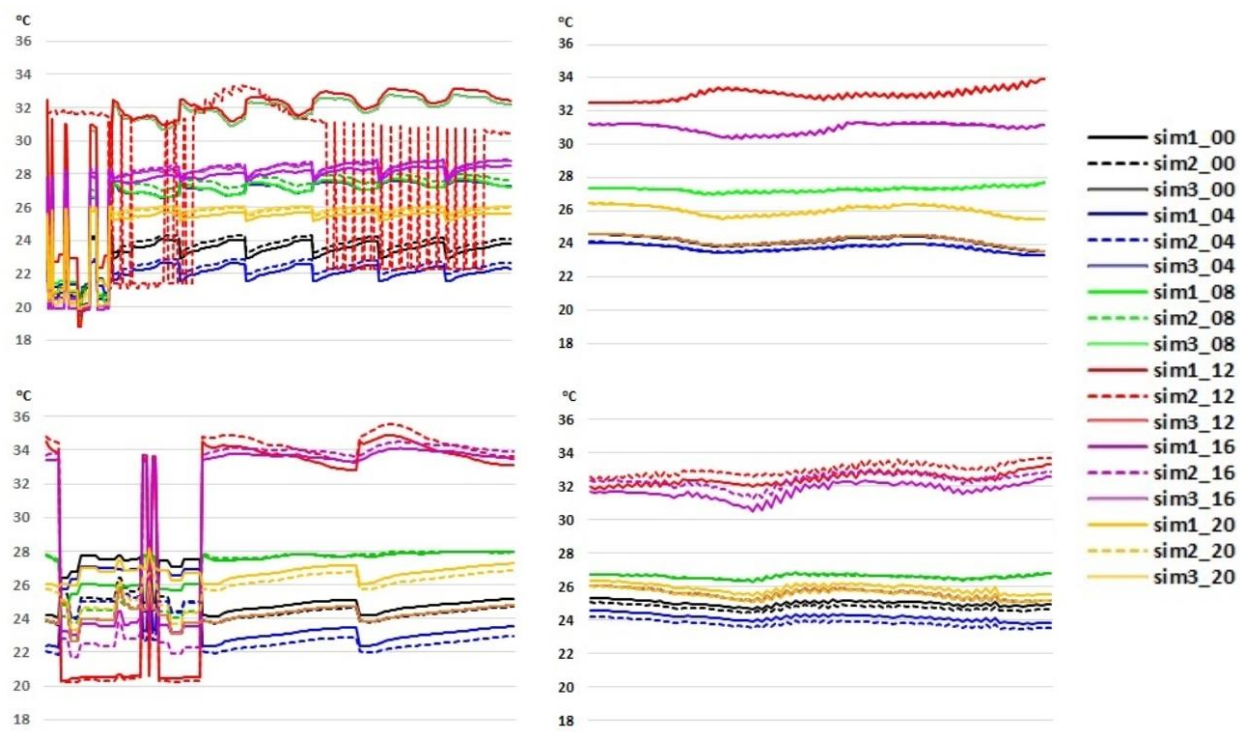

Fig. 5. Ta profiles at 00:00, 04:00, 08:00, 12:00, 16:00 and 20:00 of US canyon (left-above), PT canyon (right-above), AS canyon (left-bottom), and CS canyon (right-bottom)

\section{CONCLUSIONS}

Current microclimate models allow users to investigate the contribution of façade materials to CLHI. The validation study confirms the ENVI-met accuracy in predicting the Ta in the canopy layer when the initial wind speed at the boundary layer for input data is $>$ $1.5 \mathrm{~m} / \mathrm{s}$. The analysis feature to compare two simulation scenarios offers a facility to conduct an experimental study with variation in façade material properties. Simulations of one-day Ta show that the effect of the thermal and radiative properties of façade materials on the canyon Ta depends on the street orientation, the presence of big trees along the street and the canyon aspect ratio or SVF. The comparison maps of simulation results between urban areas with existing façade material and the ones with $45 \mathrm{~cm}$-thick, burned brick show a slight increase in the Ta in the daytime. Adding high $\alpha$ coating on the external surface walls can reduce the $\mathrm{Ta}$ in the daytime, but raise the $\mathrm{Ta}$ in the early morning and the night.

\section{ACKNOWLEDGMENTS}

The authors gratefully acknowledge the funding from Directorate of Research and Social Service, the Directorate General of Strengthening Research and Development, Ministry of Research, Technology, and Higher Education to conduct the fundamental research with the contract number 227/SP2H/LT/DRPM/2019. We also thank Monika Agustia, Arie Christoph, Alb. Ari S., and M. Krisna for their assistance during simulation and field surveys. 


\section{R E F E R E N C E S}

Acero, J. A. \& Herranz-Pascual, K. (2015) A comparison of thermal comfort conditions in four urban spaces by means of measurements and modeling techniques, Build Enviro, 93 (2), 245-257, DOI:10.1016/j.buildenv.

American Society of Heating, Refrigerating and Air Conditioning Engineers (ASHRAE) (1997) Fundamental Handbook, ASHRAE, Atlanta, USA, ISBN: 9781883413446.

Binarti, F., Koerniawan, M. D., Triyadi, S. \& Utami, S. S. (2020a) Maximizing the ENVI-met capability of modeling the Mean Radiant Temperature of a tropical archaeological site, IOP Conference Series: Earth and Environmental Science of $4^{\text {th }}$ Int. Conference on Energy and Environmental Science (ICEES 2020), 8-10 ${ }^{\text {th }}$ January, Perth (will be published).

Binarti, F., Pranowo, P. \& Leksono, S. B. (2020b) Thermal Infrared Images to Identify the Contribution of Surface Materials to the Canopy Layer Heat Island in Hot-humid Urban Areas, submitted to Environmental and Climate Technologies.

Chen, Y-C., Lin, T-P. \& Matzarakis, A. (2014) Comparison of mean radiant temperature from field experiment and modeling: a case study in Freiburg, Germany, Theor Appl Climatol, 118, 535551.

Chokhachian, A., Perini, K., Dong, M. S. \& Auer, T. (2017) How Material Performance of Building Façade Affect Urban Microclimate, Proceedings of Powerskin Conference, $19^{\text {th }}$ January 2017, Munich, Germany.

ENVI-met v.4.4.3. Available from: envi-met.com [Accessed 29th September 2019].

Erell, E., Pearlmutter, D., Boneh, D. \& Kutiel, P. B. (2014) Effect of high-albedo materials on pedestrian heat stress in urban street canyons, Urban Clim, 10 (2), 367-386,

DOI: 10.1016/j.uclim.

Fox, J., Osmond, P. \& Peters, A. (2018) The Effect of Building Facades on Outdoor Microclimate Reflectance Recovery from Terrestrial Multispectral Images Using a Robust Empirical Line Method, Climate, 6 (56), DOI:10.3390/cli6030056.

Gael, C. V. (2014). The influence of façade properties on the canopy layer microclimate within city blocks. $20^{\text {th }}$ Int. Congress of Biometeorology, Cleveland, $\mathrm{OH}$.

Ghaffarianhoseini, A., Berardi, U. \& Ghaffarianhoseini, A. (2015) Thermal performance characteristics of unshaded courtyards in hot and humid climates, Build Enviro, 87, 154-168.

Ivan, K. \& Benedek, J. (2017) The Assessment Relationship between Land Surface Temperature (LST) and Built-up Area in Urban Agglomeration, Case Study: Cluj-Napoca, Romania, Geographia Technica, 12(1), 64-74.

Johansson, E., Thorsson, S., Emmanuel, R \& Kruger, E. (2014) Instruments and methods in outdoor thermal comfort studies - the need for standardization, Urban Clim, 10, 346-366.

Kyriakodis, G-E. \& Santamouris, M. (2017) Using reflective pavements to mitigate urban heat island in warm climates - Results from a large scale urban mitigation project, Urban Clim, 24, 326339, DOI:10.1016/j.uclim.

Laureti, F., Martinelli, L. \& Battisti, A. (2018) Assessment and mitigation strategies to counteract overheating in urban historical areas in Rome, Climate, 6 (18).

Lee, H. \& Meyer H. (2018) Thermal comfort of pedestrians in an urban street canyon in an urban street canyon is affected by increasing albedo of building walls, Int. J Biometeorol, 62 (7), 11991209, doi:10.1007/s00484-018-1523-5.

Lindberg, F. \& Grimmond, C. S. B. (2010) Continuous sky view factor maps from high resolution urban digital elevation models, Clim Res, 42, 177-183, DOI:10.3354/cr00882. 
Nyuk Hien, W., Ignatius, M., Eliza, A., Jusuf, S. K. \& Samsudin, R. (2012) Comparison of STEVE and ENVI-met as temperature prediction models for Singapore context, Int $J$ of Sustainable Build Tech Urb. Dev., 3 (3), 197-209, DOI:10.1080/2093761X.

Paramita, B. \& Suparta, W. (2019) Alteration of Urban Microclimate in Bandung, Indonesia Based on Urban Morphology, Geographia Technica, 14 (Special issue), 213-220.

Salata, F., Golasi, I., de Lieto Vollaro, R. \& de Lieto Vollaro, A. (2016) Urban microclimate and outdoor thermal comfort, a proper procedure to fit ENVI-met simulation outputs to experimental data, Sustain Cities Soc, 26, 318-343.

Santamouris, M., Gaitani, N., Spanou, A., Saliari, M., Giannopoulou, K. \& Vasilakopoulou, K. (2012) Using cool paving materials to improve microclimate of urban areas - Design realization and results of flisvos project, Build Enviro, 53, 128-136.

Sen, S. (2015) Impact of Pavement on the Urban Heat Island. Master thesis, University of Illinois at Urbana Campaign, Illinois, US.

Sharmin, T., Steemers, K. \& Matzarakis, A. (2017) Microclimatic modeling in assessing the impact of urban geometry on urban thermal environment, Sustain Cities Soc, 34, 293-308.

Taleghani, M. (2018) The impact of increasing urban surface albedo on outdoor summer thermal comfort within a university campus, Urban Clim, 24, 175-184.

Ursu, C-D. (2019) The land surface temperature evolution (LST) using Landsat scenes. Case study: the industrial platform Săvineşti. Geographia Technica, 14(2), 131-142. DOI: 10.21163/GT_2019.142.12

Wicahyani, S., Sasongko, S. B. \& Izzati, M. (2014) Pulau Bahang Kota (Urban Heat Island) di Kota Yogyakarta dan Daerah Sekitarnya Hasil Interpretasi Citra Landsat OLI-TIRS Tahun 2013, Jurnal Geografi, 11 (2), doi:10.15294/jg.v11i2.8027. 